\title{
Editorial
}

\section{Our links with the past: the value of knowing our history}

For the greater part of the past century and a half the hazards and problems of anaesthesia loomed large. They were serious and frequent enough for Dr. Wesley Bourne to suggest that the anaesthetist of that era was "holding

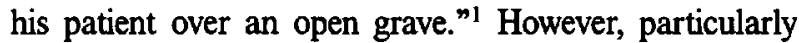
in the past 25 years, advances have made anaesthesia relatively safe and straightforward and relatively free of hazard and stress. From our perspective today it is therefore difficult to visualize our predecessors' problems and the solutions they applied. A backward look is not entirely academic because some of the basic problems (e.g., control of the airway, preservation of homeostasis and provision of analgesia and muscle relaxation) of their day are not dissimilar to ours, while the keys to solving them, then as now, have always been cut from a continuing commitment to self-education. This is nicely illustrated in the autobiographical review left to us by the late Dr. Nicholas Hill. Besides broadening our perspective through a knowledge of history, his account merits our attention for several other reasons.

Dr. N.P. Hill practised in St. Catharines, Ontario, from the mid-1920s to the early 1970s. The title of his narrative, "Fifty Years in Anaesthesia," suggests one reason why his account is of interest. The experience he gained as extraordinary and exciting advances shaped and reshaped the practice of anaesthesia during that time enabled him to write a first-hand summary of what happened. He witnessed the following advances in both drugs and techniques:

- the original inhalational agents (ether and chloroform and later ethyl chloride) through cyclopropane and trichlorethylene yielded primacy to halothane, fluroxene, methoxyflurane, which in turn gave way to isoflurane.

- the early intravenous barbiturate hypnotics (e.g., sodium amytal) were superseded by hexobarbital, sodium pentothal and methohexital, which were augmented later by a variety of other agents (e.g., the steroid hydroxydione [Althesin], ketamine, Etomidate, benzodiazepines) and then propofol.
- the opiates morphine and meperidine largely gave way to the fentanyl family of opioids and neuroleptic agents.

- the introduction of an entirely new concept of specific muscle relaxation with the advent of d-tubocurarine and depolarizing agents and other members of the nondepolarizing "family" members down to pancuronium.

- as far as techniques are concerned, the introduction of the closed circuit and mechanical, or controlled, ventilation constituted a profound change in practice, as did invasive monitoring, but refinements in spinal and epidural anaesthesia were also important.

For a quick refresher course in how anaesthesia evolved from the 1920s to the early 1970 s one need go no further than Dr. Hill's summary.

The second reason why Dr. Hill's article is of great interest lies in his remarkable commitment to lifelong selfeducation in anaesthesia. To his great credit, he took great pains and much time in learning about each new advance in order to apply it to his own practice. Nor was it a matter of relying on standard conferences; Dr. Hill preferred to take a mini-sabbatical, at his own expense, with an authority on a particular drug or technique. His article is a testament to an important principle of continuing education: learning is most efficient and effective when one perceives the need to learn and then how and when it can be applied in practice. How many of us take continuing education as seriously as did Dr. Hill? His article provides much food for thought in this respect, for it gives us insight into the attitude of a conscientious and diligent anaesthetist for whom improvements in competence and performance were highly important. Reading Dr. Hill's story may stimulate us to reassess our own methods of continuing medical education.

The third reason for an interest in this account of anaesthesia in former times is more subtle yet profoundly relevant to what we as anaesthetists do. Only by understanding what (other) anaesthetists do, and try to do, can we fully comprehend the essence of the anaesthetist's task 
as a physician; that is, what it means, for each of us, to be an anaesthetist. Here a knowledge of the history of anaesthesia is of value, because it is only through such knowledge that we can learn what former anaesthetists have had to say about the specialty and how they conducted themselves, both as physicians and as anaesthetists trying to solve the various problems of the practice of anaesthesia. It is history that links us to our predecessors and gives us commonality with them. From John Snow onwards, the leaders of our specialty, through their deeds but more particularly their words, serve as models in this respect. Dr. Hill recognized that "there were giants in the land in those days," and it was to them that he went in continuing his education; but it is through a knowledge of history that we ourselves can keep in touch with those "giants." In his turn, Dr. Hill can, through the link of history, teach us how he went about educating himself. In this article, which he wrote in 1974 but which is published in 1995, it seems that he is still with us.

A word about the decision to publish this article, posthumously, is in order. After Dr. Hill wrote it, the manuscript was deposited in due course in the Society's archives, but there it lay unread and therefore unshared and unappreciated. To be of value an archive must be used. The essence of what Dr. Hill had to say in 1974 is still relevant, and it therefore merits publication today.

\section{Les liens avec le passé: l'importance de connaître son histoire}

Pendant un siêgle et demi, les problèmes et les périls inhérents à l'anesthésie semblaient énormes. Leur gravité et leur fréquence étaient très grandes; ce qui fit dire au Dr. Wesley Bourne qu'à cette époque les anesthésistes " tenaient leurs patients au-dessus d'une tombe ouverte $1 .{ }^{1}$ Cependant, surtout au cours des 50 dernières années, on peut dire que l'anesthésie a fait des progrès remarquable au regard de la sécurité et de l'atténuation du risque. Il est difficile avec nos yeux d'aujourd hui de voir les problèmes de nos prédécesseurs et les solutions qu'ils y ont appliquées. Un regard en arrière ne peut être entièrement scientifique parce que leurs problèmes courants (par ex., la gestion des voies aériennes, l'homéostasie, l'administration de l'analgésie et la relaxation musculaire) ne sont pas différents des nôtres, alors que leurs solutions, tant hier qu'aujourd'hui, dépendent toujours de notre engagement constant envers l'auto-enseignement. Ceci est illustré finement dans le survol autobiographique que nous a laissé le regretté Dr Nicholas Hill. En plus d'elargir nos horizons par une meilleur connaissance de l'histoire, son exposé mérite notre attention pour plusieurs raisons.

Le Dr N.P. Hill a exercé à St. Catharines en Ontario à partir du milieu des années 1920 jusqu'au début des années 70. Le titre de son récit, "Cinquante années en anesthésie " laisse deviner une raison de son intérêt. L'expérience accumulée au moment où des progrès extraordinaires et excitants survenaient, lui a permis d'écrire un résumé de première main de ces événements. Il fut un témoin attentifs de lévolution des agents et des techniques suivants:

les agents inhalatoires principaux (l'etther, le chloroforme et plus tard le chlorure d'éthyle) en passant par le cyclopropane et le trichloréthylène qui ont cédé leur place à l'halothane, au fluroxène, au méthoxyflurane, qui a leur tour furent remplacés par l'isoflurane;

- les premiers hypnotiques barbituriques intraveineux (p. ex., l'amytal sodique) ont été remplacés par le pentothal sodique et le méthohexital, auxquels s'ajoutèrent plusieurs nouveaux agents (par ex., le stéroïde hydroxydione (Althesin), la kétamine, l'étomidate, les benzodiazepines) et finalement le propofol;

- les opiacés, morphine et mépéridine ont cédé leur place à une nouvelle famille de morphiniques provenant du fentanyl et aux neuroleptiques;

- l'introduction d'un concept entièrement nouveau de la relaxation musculaire avec l'arrivée de la d-tubocurarine et des agents dépolarisant et d'une nouvelle classe de non dépolarisants dont le pancuronium;

- en ce qui concerne les techniques, l'introduction du circuit avec absorption et de la ventilation mécanique, ont constitué une changement majeur de la pratique, avec le monitorage effractif, mais le perfectionnement de l'anesthésie rachidienne et épidurale a aussi eu son importance.

Pour une mise à jour de l'évolution de l'anesthésie de 1920 à 1970 , nous devrons pousser un peu plus loin que ne le permet le résumé du Dr Hill.

La deuxième raison de l'intérêt suscité par l'article du Dr Hill repose par son irréductible engagement envers l'auto-enseignement. Il a dévoué beaucoup d'efforts et de temps pour se familiariser avec toutes les innovations afin de les 'appliquer à sa pratique. Il se fiait peu aux conférences formelles; il préférait prendre des mini-congés sabbatiques, à ses frais, avec un collègue reconnu pour 
sa compétence dans un domaine particulier de la pharmacologie ou de la technique. Son article constitue un testament à une principe de l'éducation médicale permanente; apprendre est plus efficace quand on en perçoit le besoin et lorqu'on sait quand et comment on peut appliquer une connaissance à la pratique. Combien parmi nous perçoivent l'éducation permanente aussi sérieusement que le Dr Hill? Sur cet aspect, son article fournit beaucoup d'eau au moulin, parce qu'il nous donne une idée de l'attitude d'un anesthésiste consciencieux et diligent pour lequel le perfectionnement de la compétence et de la performance comptait beaucoup. La lecture de lhistoire du Dr Hill devrait nous inciter à revoir nos propres méthodes d'éducation permanente.

La troisième raison de l'intérêt suscité par ce récit de l'anesthésie du temps passé et plus subtile mais extrêmement pertinente en ce qui concerne la profession d'anesthésiste. Ce n'est uniquement en comprenant ce que les autres font, ou essayent de faire, que nous pouvons comprendre l'essence même de la tâche de l'anesthésiste comme médecin; en d'autres termes, comment être un anesthésiste. Pour cela, la connaissance de l'histoire de l'anesthésie a beaucoup de prix parce que ce n'est seulement qu'avec cette connaissance que nous pouvons apprendre ce que les anesthésistes qui nous ont précédé avaient à dire sur notre discipline et comment ils s'y sont pris en tant que médecins et anesthésistes pour tenter de résoudre les différents problèmes inhérents à l'exercice de l'anesthésie. C'est l'histoire qui établit le lien avec nos prédécesseurs et qui nous les rapproche. Depuis John Snow, les leaders do notre spécialité, par leurs réalisations mais encore plus particulièrement par leurs écrits, nous servent de modèles. Le Dr Hill reconnaît " quil y avait, dans ce temps-là, des géants sur la terre " et c'est vers eux qu'il allait pour parfaire ses connaissances; c'est par la connaissance de l'histoire que nous pouvons nousmêmes rester en contact avec ces " géants". A son tour, le Dr Hill peut, en continuité avec l'histoire, nous enseigner comment il s'est lui-même éduqué. Dans cet article, écrit en 1974 mais publié en 1995, on le croirait toujours parmis nous.

Un mot sur la décision de publier ce travail posthume simpose. Après sa rédaction, le manuscrit du Dr Hill fut déposé comme il se devait dans les archives de la Société, mais il est resté là sans qu'on ne le lise et par conséquent, il y est demeuré caché et méconnu. Pour avoir de la valeur, une archive doit être utilisée. L'essentiel de ce que le Dr Hill avait à dire en 1974 est encore pertinent. Il mérite donc d'être publié aujourd hui.

\section{Reference}

1 Bourne, $W$. Cited by Hill NP. Unpublished portion of manuscript "Fifty Years in Anaesthesia." Can J Anaesth 1995; 42: 948-51. 